\title{
Taxonomic Status of the Genus Halococcus Schoop
}

\author{
M. KOCUR AND W. HODGKISS \\ Czechoslovak Collection of Microorganisms, University of J. E. Purkyne, Brno, Czechoslovakia, \\ and Torry Research Station, Aberdeen, Scotland
}

\begin{abstract}
Twenty-two strains of extremely halophilic cocci (i.e., cocci requiring at least $15 \% \mathrm{NaCl}$ for growth), so far considered as belonging to species of the genus Micrococcus Cohn or Sarcina Goodsir, were subjected to a taxonomic analysis. As a result of this study, it is recommended that they be assigned to the genus Halococcus Schoop, 1935. Amended descriptions of the genus and its single species, H. morrhuae (Farlow 1880) comb. nov., are given. CCM 537 (ATCC 17082, NCMB 787) is designated as the neotype strain of $H$. morrhuae.
\end{abstract}

Although gram-negative, extremely halophilic, red cocci have been known for 90 years, their nomenclature and classification are still confused. These organisms are commonly referred to under the name Sarcina litoralis Poulsen (synonym, Micrococcus litoralis [Poulsen] Kellerman) or $S$. morrhuae Farlow (synonym, $M$. morrhuae [Farlow] Klebahn). It has not been clear whether these organisms belong to the genus Sarcina or Micrococcus or whether some belong to one genus and some belong to the other.

For a long time the opinion prevailed (15) that the first red, halophilic coccus described was that by Poulsen (29) under the name $S$. litoralis. However, examination of the original description of Poulsen's organism shows that it was not a red, extremely halophilic organism (22). Undoubtedly the first red, halophilic coccus was described in 1880 by Farlow (10) under the name $S$. morrhuae.

Several attempts have been made to improve the classification of halophilic cocci. Kellerman (18) recommended placing them in the genus Micrococcus as $M$. litoralis (basionym, $S$. litoralis Poulsen). Klebahn (19) also suggested their placement in the genus Micrococcus but as $M$. morrhuae (basionym, $S$. morrhuae Farlow). Schoop (30) suggested that the extremely halophilic cocci be placed in a separate genus, Halococcus. Unfortunately his suggestion was supported by only a few authors $(22,37)$. Some authors $(18,19,22,28,30)$ recognized only a single species among the extremely halophilic cocci, whereas others (e.g., 15, 36) accepted both $S$. litoralis and $M$. morrhuae.

The aim of the present paper is to clarify the taxonomy of the red, extremely halophilic cocci and to make any nomenclatural changes indicated.

\section{MATERIALS AND METHODS}

Bacterial strains. Twenty-two strains of halophilic cocci were investigated (Table 1).

Methods. Stock cultures were maintained on the medium of Payne et al. (27), which has the following composition (g/liter): Casamino Acids, 7.5; yeast extract, $10.0 ;$ trisodium citrate, $3.0 ; \mathrm{KCl}, 2.0$; $\mathrm{MgSO}_{4} \cdot 7 \mathrm{H}_{2} \mathrm{O}, 20.0 ; \mathrm{FeSO}_{4} \cdot 7 \mathrm{H}_{2} \mathrm{O}, 0.05 ; \mathrm{MnSO}_{4} \cdot$ $4 \mathrm{H}_{2} \mathrm{O}, 0.25 \mathrm{mg} ; \mathrm{NaCl}, 250.0$; and agar, 20.0.

For morphological, cultural, and physiological studies, cultures were incubated for 7 days, and all tests were carried out at $37 \mathrm{C}$ unless otherwise indicated. Two methods for Gram staining were used: (i) Hucker's (14) modification and (ii) Dussault's method (9). Colony characteristics were observed both on the halophile medium of Payne et al. (27) and on the salt-milk agar medium of Sreenivasan and Venkataraman (33), which consisted of: (i) sterile skim milk, $500 \mathrm{ml}$; (ii) salt solution: $\mathrm{MgSO}_{4} \cdot 7 \mathrm{H}_{2} \mathrm{O}, 10 \mathrm{~g} ; \mathrm{KNO}_{3}$, $2 \mathrm{~g} ; \mathrm{NaCl}, 200 \mathrm{~g}$; ferric citrate, traces; in $100 \mathrm{ml}$ of water; and (iii) agar (Difco), 15 g; neopeptone (Difco), $5 \mathrm{~g}$; glycerol, $10 \mathrm{~g}$; and water, $400 \mathrm{ml}$. The three solutions were steamed separately, (ii) and (iii) were mixed together, and the $\mathrm{pH}$ was adjusted to 8.4 with $0.1 \mathrm{~N} \mathrm{NaOH}$. The agar-salt mixture was autoclaved at $15-1 b /$ in $^{2}$ pressure for $20 \mathrm{~min}$. The hot mixture was aseptically added to the warm skim milk. This medium served also for the detection of casein hydrolysis.

The utilization of glucose was determined in a standard glucose medium (34) containing $20 \% \mathrm{NaCl}$. Citrate utilization was tested for on Simmons' citrate agar (Difco) containing 20\% $\mathrm{NaCl}$. Catalase was detected by flooding the growth on plates with $3 \%$ $\mathrm{H}_{2} \mathrm{O}_{2}$. The benzidine test for porphyrin was carried 
TABLE 1. List of strains used ${ }^{a}$

\begin{tabular}{|c|c|c|}
\hline Previously identified as & Collection no. & Other names or no. \\
\hline Micrococcus morrhuae & $\begin{array}{l}\text { CCM } 537 \\
\text { CCM } 859 \\
\text { CCM } 889 \\
\text { CCM } 2224 \\
\text { CCM } 2226 \\
\text { NCMB } 724 \\
\text { NCMB } 748\end{array}$ & $\begin{array}{l}\text { Sarcina litoralis, C. B. } \\
\quad \text { van Niel L.D.3.1.; ATCC 17082; } \\
\quad \text { NCMB } 787 \\
\text { C. B. van Niel L.A.7.2. } \\
\text { Strain Delft } \\
\text { H. Larsen } 24 \\
\text { R. Venkataraman H4 } \\
\text { B. Elazari-Volcani }\end{array}$ \\
\hline Microccocus sp. & $\begin{array}{l}\text { NCMB } 723 \\
\text { NCMB } 751 \\
\text { NCMB } 752 \\
\text { NCMB } 753 \\
\text { NCMB } 754\end{array}$ & $\begin{array}{l}\text { R. Venkataraman H3 } \\
\text { J. M. Shewan Q coccus } \\
\text { J. M. Shewan Q coccus } \\
\text { J. M. Shewan Q coccus } \\
\text { Myxococcus }\end{array}$ \\
\hline Sarcina litoralis & NCMB 757 & A. G. Lochhead \\
\hline S. marina & NCMB 778 & \\
\hline S. morrhuae & NCMB 761 & B. Elazari-Volcani 9.5 \\
\hline S. morrhuae & NCMB 746 & D. A. A. Mossel \\
\hline S. sreenivasani & NCMB 776 & \\
\hline Sarcina sp. & $\begin{array}{l}\text { NCMB } 722 \\
\text { NCMB } 755 \\
\text { NCMB } 759 \\
\text { NCMB } 728 \\
\text { NCMB } 756\end{array}$ & $\begin{array}{l}\text { R. Venkataraman H2 } \\
\text { A. G. Lochhead } \\
\text { TRS } \\
\text { R. Venkataraman H15 } \\
\text { A. G. Lochhead } 63 \text { R1 }\end{array}$ \\
\hline
\end{tabular}

${ }^{a}$ ATCC, American Type Culture Collection, Rockville, Md.; CCM, Czechoslovak Collection of Microorganisms, Brno; NCMB, National Collection of Marine Bacteria, Torry Research Station, Aberdeen, Scotland.

out by the method of Deibel and Evans (8), and the production of oxidase was determined by the method of Gaby and Hadley (11).

Two media were used for detecting gelatin hydrolysis: (i) the medium of Clarke (5), which is a mixture of nine parts of nutrient agar and one part of $10 \%$ gelatin with $25 \% \mathrm{NaCl}$ (after 7, 14, and 21 days the inoculated plates were flooded with mercuric chloride; a clear zone larger than $0.2 \mathrm{~mm}$ was interpreted as positive); and (ii) the medium of Sreenivasan and Venkataraman (33), consisting of proteose-peptone (Difco), $10.0 \mathrm{~g}$; yeast extract (Difco), $2.5 \mathrm{~g} ; \mathrm{MgSO}_{4}$. $7 \mathrm{H}_{2} \mathrm{O}, 10.0 \mathrm{~g} ; \mathrm{KNO}_{3}, 2.5 \mathrm{~g} ; \mathrm{NaCl}, 250.0 \mathrm{~g}$; agar, 20.0 $\mathrm{g}$; and distilled water, $900 \mathrm{ml}(\mathrm{pH}$ adjusted to 7.6$)$. After sterilization of the mixture at a pressure of 15 $\mathrm{lb} / \mathrm{in}^{2}$ for $20 \mathrm{~min}, 5 \mathrm{~g}$ of gelatin in $100 \mathrm{ml}$ of distilled water, which were sterilized separately, was added. The plates were inoculated, incubated, and then flooded with $5 \%$ trichloroacetic acid. Clear zones around the streaks were regarded as positive reactions.

Nitrate reduction was determined in the medium recommended by Sreenivasan and Venkataraman (33), with the following composition ( $\mathrm{g} /$ liter): Casitone (Difco), 10.0 ; yeast extract (Difco), $5.0 ; \mathrm{MgSO}_{4} \cdot$ $7 \mathrm{H}_{2} \mathrm{O}, 10.0 ; \mathrm{NaCl}, 250.0$; and $\mathrm{KNO}_{3}, 2.5$.
Nitrite reduction was tested for in the following medium (g/liter): peptone (Difco), $10 ; \mathrm{NaCl}, 250.0$; $\mathrm{NaNO}_{2}, 0.005$; and agar (Difco), 2.5. The presence of nitrite was detected by adding five drops of $0.8 \%$ sulfanilic acid in $5 \mathrm{~N}$ acetic acid and five drops of $0.5 \%$ $\alpha$-naphthylamine in $5 \mathrm{~N}$ acetic acid to cultures grown in the above-mentioned medium. A red color indicated the presence of nitrite and therefore the absence of nitrite reduction.

Starch hydrolysis was determined by the methods of Sreenivasan and Venkataraman (33) and Gibbons (12). Growth on plates was flooded with Lugol's iodine after 7 and 14 days of incubation.

Indole production was determined by Gore's method (13) by using a medium recommended by Gibbons (12), which contains $20 \% \mathrm{NaCl}$, and by Kovacs' reagent by using the medium of Sreenivasan and Venkataraman (33).

The production of hydrogen sulfide was detected by two methods: (i) by means of a strip of lead acetate paper inserted in the mouth of a tube containing the same medium used in testing for indole production; and (ii) by flooding salt-milk-agar plates containing growth with lead acetate as recommended by Anderson (1). 
The presence of a Tween-80-splitting enzyme was determined by spot inoculations of Sierra's medium (31), modified as follows (g/liter): peptone (Difco), 10; $\mathrm{NaCl}, 250.0 ; \mathrm{CaCl}_{2} \cdot 2 \mathrm{H}_{2} \mathrm{O}, 0.1$; Tween 80, 10.0, and agar, 20.0. Enzymatic activity was indicated by the presence of opacity around the culture after 3 to 7 days of incubation.

Pigment formation was examined on all solid media used and at different temperatures.

\section{RESULTS}

Morphology. All of the strains studied were gram-negative cocci when stained by both the method of Hucker (14) and of Dussault (9). The cells occurred in isolated tetrads or in irregular clumps of tetrads. The average size of the cells was 0.8 to $1.0 \mu \mathrm{m}$. All strains were nonmotile and nonsporeforming.

Cultural characteristics. The strains formed one of two types of colonies on the medium for halophiles (27): (i) 11 strains produced circular, convex, smooth, and glistening colonies; and (ii) the other 11 strains formed irregular, butyrous, rough, and matted colonies. All strains studied formed a pink to brick-red pigment on most media used. They grew very poorly in liquid media, both in deep tubes and in shallow layers. The optimal growth of all strains was obtained on media with 20 to $25 \%$ $\mathrm{NaCl}$ at $37 \mathrm{C}$. The best growth was produced on the salt-milk medium of Venkataraman and Sreenivasan '(33) and on the halophile medium of Payne et al. (27). None of the strains tested grew on media containing less than $15 \% \mathrm{NaCl}$ or at $45 \mathrm{C}$.

Biochemical characteristics. All of the strains produced catalase and a positive benzidine test for porphyrin, and all reduced nitrates within 7 to 10 days. Both methods $(5,33)$ used for the detection of gelatin hydrolysis gave identical results in each case: gelatin was hydrolyzed by the same eight strains after 7 days of cultivation. The splitting of Tween 80 by 10 strains was detected between 3 to 7 days of cultivation. Indole production was positive by 14 strains when tested for by the method of Gore (13) after 7 days in the medium recommended by Gibbons (12). No indole production was observed by any of the strains when grown in the medium of Sreenivasan and Venkataraman (33) and when Kovács' reagent was used. None of the strains studied produced oxidase, utilized glucose or citrate, hydrolyzed casein or esculin, or reduced nitrite, nor did they hydrolyze starch when tested by the methods of Sreenivasan and Venkataraman (33) and Gibbons (12).

\section{DISCUSSION}

Except for minor differences, the results of our study are in agreement with the data obtained by other authors $(12,36,37)$ who studied the extremely halophilic cocci. One difference of note was detected: none of the 22 strains examined hydrolyzed starch, although Venkataraman and Sreenivasan (36) found this test positive in 5 of 10 strains, and Gibbons (12) found it positive in 5 of 13 strains. Gibbons (12) noticed these differences in the results of various authors and pointed out that a loss of ability to hydrolyze starch may occur after long periods of maintenance in laboratory media.

Strain NCMB 756 was previously studied by Lochhead (24), and NCMB 728 was studied by Venkataraman and Sreenivasan (36). Our results on these two strains are in accord with the data of these authors.

Although the strains studied were originally labeled as belonging to a number of different species (see Table 1), our results suggest that all of them belong to a single species, a conclusion which is in agreement with the opinions of other authors $(6,23,28,30)$. However, doubts have existed as to whether halophilic cocci should be regarded as members of the genus Sarcina Goodsir or Micrococcus Cohn. They cannot be placed in the genus Sarcina because this genus consists of strictly anaerobic species with 28 to $30 \mathrm{~mol} \%$ guanine plus cytosine (GC) in their deoxyribonucleic acid (DNA). Furthermore, the halophilic cocci cannot be properly classified in the genus Micrococcus because of their following characteristics: (i) they are gram negative; (ii) their cell walls are fundamentally different from those of micrococci, consisting of polysaccharides, whereas those of micrococci contain peptidoglycans $(4,17)$; (iii) they grow in 15 to $30 \% \mathrm{NaCl}$, whereas micrococci do not grow at this concentration of salt at all; (iv) they contain normal menaquinones, whereas micrococci contain hydrogenated menaquinones (16); (v) the GC content of their DNA $(57-66 \%)$ is somewhat lower than that of most strains of micrococci, which have a GC content of 65 to $75 \%(3,20)$; and (vi) their red pigment is bacterioruberin (35), whereas micrococci contain predominantly zeaxanthin (32) or canthaxanthin (7) pigments.

Therefore, we recommend that the halophilic cocci be placed in a separate genus, Halococcus Schoop, which originally included a single species of red, halophilic cocci, $H$. litoralis (Poulsen) Schoop (basionym, S. litoralis Poulsen), which is the type species by monotypy. However, it appears that the type species was 
incorrectly identified as belonging to $S$. litoralis. An examination of Poulsen's paper (29) reveals that the organism he described under the name $S$. litoralis was not a red, extremely halophilic coccus, and thus Schoop (30) was in error in identifying his isolates as belonging to $S$. litoralis. A similar error was made by Kellerman (1915), who designated his isolates of red halophilic cocci as $M$. litoralis (basionym, S. litoralis Poulsen). Apparently Farlow (10) was the first to name and describe red, halophilic cocci, and he gave them the name $S$. morrhuae. A comparison of Schoop's description of his isolates with the original description of $S$. morrhuae shows both descriptions to be in agreement. Thus, the correct identification of Schoop's isolates is with $S$. morrhuae Farlow 1880 and not with $S$. litoralis Poulsen 1879 . Consequently, we propose the new combination $H$. morrhuae (basionym, S. morrhuae Farlow) for Schoop's organism. Schoop's organism, on which the original description of the genus was based, still remains the type species of the genus Halococcus. The specific epithet in the name of the type species merely has been changed to reflect the correct identity of Schoop's isolates.

Since none of Farlow's original strains is extant, strain CCM 537 of the Czechoslovak Collection of Microorganisms, which has the characters originally given for $S$. morrhuae by Farlow, is designated here as the neotype strain of $H$. morrhuae. This strain was received from C. B. van Niel with the designation L.D. 3.1; van Niel received it from B. Elazari-Volcani, who isolated it from the Red Sea. It has been deposited in the American Type Culture Collection, Rockville, Md., as ATCC 17082 and in the National Collection of Marine Bacteria, Aberdeen, Scotland, as NCMB 787. A description of this strain is given below.

Because the original description of the genus Halococcus is inadequate in terms of presentday knowledge, we suggest that it be amended as follows.

Genus Halococcus Schoop 1935, 817

Hal.o.coc ćus Gr. noun hals, salt; Gr. noun coccus, a berry; M.L. mas.n. Halococcus, salt coccus.

Cocci, 0.8 to $1.5 \mu \mathrm{m}$ in diameter, occurring in isolated tetrads and in large, irregular clusters of tetrads. Nonmotile. Endospores not produced. Gram negative. The cell wall consists of a single layer 55 to $60 \mathrm{~nm}$ thick and has a structure similar to that of the cell wall of species in the genus Halobacterium: it contains polysaccharides but no peptidoglycan $(4,17$,
23). The cytoplasm contains nucleoids, mesosomes, gas vacuoles, and polyphosphate granules (21).

Chemoorganotrophic, the metabolism being respiratory, never fermentative. Oxidase positive. Glucose and other carbohydrates not attacked. Catalase positive. The benzidine test for porphyrin is positive. Nitrate is reduced to nitrite without production of gas. A carotenoid pigment, bacterioruberin $(26,35)$, is produced, as are normal menaquinones (16). Extremely halophilic, requiring at least $15 \% \mathrm{NaCl}$ for growth. Aerobic, growing best on the surface of solid media.

Temperature range: Good growth between 30 to $37 \mathrm{C}$.

Saprophytic.

Distributed in strong brines and sea water, especially in warmer climates, in solar-salt production areas associated with a red discoloration of salted fish, and in hides which are processed with solar salts.

The guanine plus cytosine content in the DNA ranges from 57 to $66 \mathrm{~mol} \%(3,20,25)$. Type species: $H$ morrhuae (Farlow) comb. nov.

(S. morrhuae Farlow 1880, 947; strains described by Schoop 1935 under the name $S$. litoralis Poulsen, but $H$. morrhuae is not $S$. litoralis Poulsen; M. morrhuae (Farlow 1880) Klebahn 1919,47.)

morr.hu áe. M.L.n. morrhua specific epithet in the name of the codfish, Cadus morrhua; M.L.gen.n. morrhuae of morrhua. (Percentages indicate the ratio of strains studied which are positive for the character cited.)

Morphology as for the genus. Extremely halophilic, good growth occurring in media with 15 to $25 \% \mathrm{NaCl}$; do not grow on media containing less than $15 \% \mathrm{NaCl}$. All characteristics reported below were determined in or on media containing $20 \% \mathrm{NaCl}$ unless stated otherwise. Colonies on the medium of Payne et al. (27) may occur as two types: (i) circular, convex, smooth, and glistening or (ii) irregular, butyrous, rough, and matted.

Agar slant: Growth filiform, raised, matted or smooth, butyrous, pink or red.

Nutrient broth: No turbidity, sediment only.

Chemoorganotrophic: Metabolism respiratory.

Acid and gas not produced from glucose or other carbohydrates (method of Subcommittee [34]).

Catalase activity is present $(100 \%)$.

Porphyrin respiratory enzymes are present (100\%) (method of Deibel and Evans [8]).

Oxidase is positive (method of Gaby and 
Hadley [11]).

Indole is produced $(60 \%)$ (method of Gibbons [12]).

Hydrogen sulfide is not produced on Anderson's medium (method of Anderson [1]).

Hydrogen sulfide produced from cysteine $\mathrm{HCl}(75 \%)$ (Gibbons, personal communication).

Nitrate is reduced $(100 \%)$. Nitrite is not reduced.

Modified Simmons' citrate agar: No growth. Starch may be hydrolyzed $(50 \%)(12,36$, 37).

Esculin is not hydrolyzed.

Tween 80 may be split (50\%) (method of Sierra [31]).

Urease not produced.

Gelatin may be hydrolyzed $(40 \%)$ (method of Clarke [5]).

Casein seldom hydrolyzed $(36,37)$.

Pigment: Produces a pink to brick-red carotenoid pigment, bacterioruberin $(2,26,35)$.

Produces normal menaquinones (16).

Aerobic.

Good growth within 30 to $37 \mathrm{C}$.

Good growth on media with 17.5 to $25.0 \%$ $\mathrm{NaCl}$.

Resistant to lysozyme.

Saprophytic.

Habitat: Heavy sea water brine and solar sea salt; also found in red discoloration of salted fish and hides in which solar salts are used.

The guanine plus cytosine content of the DNA is 57 to $66 \mathrm{~mol} \%(3,20,25)$.

Description of the neotype strain (ATCC $17082=\mathrm{CCM} 537=\mathrm{NCMB} 787)$ of $M$. morrhuae.

Spheres, 0.8 to $1.0 \mu \mathrm{m}$ in diameter, occurring in tetrads. Nonmotile. Endospores not produced. Gram negative.

Extremely halophilic, good growth in media containing 15 to $25 \% \mathrm{NaCl}$; does not grow on media containing less than $15 \% \mathrm{NaCl}$.

Colonies on the medium of Payne et al. (27) are irregular, butyrous, matted, and red.

Agar slant: Growth filiform, raised, matted or smooth, butyrous, and red.

Nutrient broth: No turbidity; sediment only.

Chemoorganotrophic: Metabolism respiratory.

Acid and gas not produced from glucose or other carbohydrates (method of Subcommittee [34]).

Catalase activity is present.

Porphyrin respiratory enzymes are present (method of Deibel and Evans [8]).

Oxidase is positive (method of Gaby and Hadley [11]).
Indole is produced (method of Gibbons [12]).

Hydrogen sulfide is not produced (method of Anderson [1]).

Nitrate is reduced. Nitrite is not reduced.

Modified Simmons' citrate agar (with 20\% $\mathrm{NaCl}$ ), no growth.

Starch is not hydrolyzed (method of Venkataraman and Sreenivasan [36, 37] and Gibbons [12]).

Esculin is not hydrolyzed.

Tween 80 is not split (method of Sierra [31]).

Urease not produced.

Gelatin is hydrolyzed (method of Clarke [5]).

Casein is not hydrolyzed.

Pigment: A pink to brick-red carotenoid is produced.

Produces normal menaquinones (16).

Aerobic.

Good growth within 30 to $37 \mathrm{C}$.

Good growth on media containing 17.5 to $25.0 \% \mathrm{NaCl}$.

Resistant to lysozyme.

Saprophytic.

The guanine plus cytosine content of the DNA is $57.8 \mathrm{~mol} \%(3)$.

\section{ACKNOWLEDGMENTS}

We are indebted to N. E. Gibbons for his advice and criticism. Some of the work described in this paper was carried out as part of the program of the Torry Research Station.

\section{REPRINT REQUESTS}

Address requests for reprints to: $M$. Kocur, Czechoslovak Collection of Microorganisms, J. E. Purkyne University, Brno, Tr. Obrancu Miru 10, Czechoslovakia.

\section{LITERATURE CITED}

1. Anderson, H. 1954. The reddening of salted hides and fish. Appl. Microbiol. 2:64-69.

2. Baxter, R. M. 1960. Carotenoid pigments of halophilic bacteria. Can. J. Microbiol. 6:417-424.

3. Boháček, J., M. Kocur, and T. Martinec. 1968. Deoxyribonucleic acid base composition of some marine and halophilic micrococci. J. Appl. Bacteriol. 31:215-219.

4. Brown, A. D., and K. Y. Cho. 1970. The walls of extremely halophilic cocci. Gram-positive bacteria lacking muramic acid. J. Gen. Microbiol. 62:267-270. 
5. Clarke, S. 1953. A simplified plate method for detecting gelatin liquefying bacteria. J. Clin. Pathol. 6:246-248.

6. Colwell, R. R., and N. E. Gibbons. 1972. Taxonomic study of some halophilic bacteria. Antonie van Leeuwenhoek J. Microbiol. Serol. $38: 27-46$.

7. Cooney, J. J., H. W. Marks, and A. M. Smith. 1966. Isolation and identification of canthaxanthin from Micrococcus roseus. J. Bacteriol. 92:311-343.

8. Deibel, R. H., and J. B. Evans. 1960. Modified benzidine test for the detection of cytochromecontaining respiratory systems in microorganisms. J. Bacteriol. 79:356-360.

9. Dussault, H. P. 1955. An improved technique for staining red halophilic bacteria. J. Bacteriol. 70:489.

10. Farlow, W. G. 1880 . On the nature of the peculiar reddening of salted codfish during the summer season. U.S. Fish Comm. Rep. for 1878, p. 969-973.

11. Gaby, W. L., and C. Hadley. 1957. Practical laboratory test for the identification of Pseudomonas aeruginosa. J. Bacteriol. 74:356-358.

12. Gibbons, N. E. 1957. The effect of salt concentration on the biochemical reactions of some halophilic bacteria. Can. J. Microbiol. 3:249-255.

13. Goré, S. N. 1921. The cotton-wool test for indole. Indian J. Med. Res. 8:505-507.

14. Hucker, G. J. 1927. Further studies on the methods of Gram staining. N.Y. State Agr. Exp. Sta. Tech. Bull. 128.

15. Hucker, G. J., and S. Breed. 1957. Genus Micrococcus, p. 462. In R. S. Breed, E. G. D. Murray, and N. R. Smith (ed.), Bergey's manual of determinative bacteriology, 7 th ed. Tindall and Cox, London.

16. Jeffries, L., M. A. Cawthorne, M. Harris, B. Cook, and T. Diplock. 1969. Menaquinone determination in the taxonomy of Micrococcaceae. J. Gen. Microbiol. 54:365-380.

17. Kandler, O., K. H. Schleifer, E. Niebler, M. Nakel, H. Zahradnik, and M. Ried. 1970. Murein types in micrococci and similar organisms. Publ. Fac. Sci. Univ. J. E. Purkyně, Brno K47: 143-156.

18. Kellerman, K. F. 1915. Micrococci causing red deterioration of salted cod fish. Zentralbl. Bakteriol. Parasitenk. Infektionskr. Hyg. Abt. 2. 42:398-402.

19. Klebahn, H. 1919. Die Schädlinge des Klippfisches. Ein Beitrag zur Kenntnis der salzliebenden Organismen. Mitt. Inst. Allg. Bot. Hamb. 4:11-69.

20. Kocur, M., and J. Boháček. 1972. DNA base composition of extreme halophilic cocci. Arch. Mikrobiol. 82:280-282.
21. Kocur, M., B. Šmid, and T. Martinec. 1972. The fine structure of extreme halophilic cocci. Microbios 5:101-107.

22. Larsen, H. 1962. Halophilism, p. 297-342. In I. C. Gunsalus and R. Y. Stanier (ed.), The bacteria, vol. 4. Academic Press Inc., New York.

23. Larsen, H. 1969. Extremely halophilic bacteria. J. Gen. Microbiol. 55:xxii-xxiii.

24. Lochhead, A. G. 1934. Bacteriological studies on the red discoloration of salted hides. Can. J. Res. 10: $275-286$.

25. Moore, L. R., and B. J. McCarthy. 1969. Characterization of the deoxyribonucleic acid of various strains of halophilic bacteria. J. Bacteriol. 99:248-254.

26. Nandy, S. C., and S. N. Sen. 1967. Chromogenesis of halophilic bacteria. Indian J. Exp. Biol. 5:146-148.

27. Payne, J. I., S. N. Seghal, and N. E. Gibbons. 1960. Immersion refractometry of some halophilic bacteria. Can. J. Microbiol. 6:9-15.

28. Petter, H. F. M. 1931. On bacteria of salted fish Proc. Kon. Med. Akad. Wetensh. 34:1417-1423.

29. Poulsen, V. A. 1880 . Om nogle mikroskopiske Planteorganismer. Et morfologisk og kritisk Studie. Vidensk. Meddel, Naturhist. Forening i Kjobenhavn 1879-80, p. 231-254.

30. Schoop, G. 1935. Halococcus litoralis, ein obligat halophiler Farbstoffbildner. Deut. Tieraerztl. Wochenschr. 43:817-820.

31. Sierra, G. 1957. A simple method for the detection of lipolytic activity of microorganisms and some observations on the influence of the contact between cells and fatty substrates. Antonie van Leeuwenhoek J. Microbiol. Serol. 23:15-22.

32. Sobin, B., and G. L. Stahly. 1942. The isolation and absorbtion spectrum maxima of bacterial carotenoid pigments. J. Bacteriol. 44:265-276.

33. Sreenivasan, A., and R. Venkataraman. 1956. Media for the study of red halophilic bacteria. J. Sci. Ind. Res. 15C:210-211.

34. Subcommittee on taxonomy of staphylococci and micrococci. 1965. Recommendation. Int. Bull. Bacteriol. Nomencl. Taxon. 15:109-110.

35. Thirkell, D., and M. S. I. Hunter. 1970. A water soluble carotenoid-glycopeptide from Sarcina morrhuae. J. Gen. Microbiol. 62:125-127.

36. Venkataraman, R., and A. Sreenivasan. 1956a. Further studies on the red halophilic bacteria from solar salts and salted fish. Proc. Indian Acad. Sci. 43:197-206.

37. Venkataraman, R., and A. Sreenivasan. 1956b. Red halophilic bacteria -the identity of some well known species. Proc. Indian Acad. Sci. 43: 264-270. 